\title{
Brian Selznick's The invention of Hugo Cabret, Martin Scorsese's Hugo, and the theft of subjectivity
}

Mark Macleod ${ }^{1}$

\begin{abstract}
Sanders (2006) and Hutcheon (2006) are among the many adaptation theorists who challenge the criterion of 'fidelity', and yet a frequent response to Martin Scorsese's Academy Award-winning film Hugo is that it is faithful to Brian Selznick's Caldecott Medalwinning book The invention of Hugo Cabret. This paper argues that in each case the medium determines a significant difference in the construction of subjectivity. The book's preoccupation with theft indicates a Lacanian concern with the origin of subjectivity and the implied author's subtextual guilt about his dependence on the work of another artist. The film's shift in emphasis to the necessity of relationships and family, however, parallels Kristeva's assumption that intertextuality is inevitable. As Geraghty (2009) points out, adaptation is by definition dependent on another text. Consequently, Scorsese's Hugo ignores the book's concern with originality and, at a time when cinema is again being repositioned by technological change, celebrates the continuity and heritage of the medium.
\end{abstract}

Keywords: Hugo. Brian Selznick. Martin Scorsese. Subjectivity. Adaptation.

The accusation most frequently hurled at the young protagonist of Brian Selznick's 2007 novel The Invention of Hugo Cabret, and Martin Scorsese's 2011 film adaptation Hugo, is that he is a thief. Beyond the orphaned child's need to steal food so that he can live, however, his theft of machine parts and his attempted theft of a book point to the implied author's personal, and perhaps partly unconscious, anxiety about his own dependence on tradition. The use of the past made by a writer or illustrator - and Selznick is both - is a more reprehensible kind of theft, albeit artistic and therefore assumed by many to be licensed.

\footnotetext{
${ }^{1}$ Mark Macleod is an Australian academic and writer for children. He has been Children's Publishing Director for Random House, publisher of his own name imprint Mark Macleod Books for Hachette Australia, a television and radio presenter and national president of the Children's Book Council of Australia. He lectures in children's literature and creative writing at Charles Sturt University, southwest of Sydney. Among his recent publications are A Treasure Chest of Rhymes (Bolinda Audio), a collection of 40 lyrics for children set to music by Peter Sullivan; the picture book Just One More (ABC Books), and Onde Deus Está? (Editora Fundamento, 2011). Email:_mmacleod@csu.edu.au.

[Mark Macleod é professor universitário e escritor australiano. É Editor-Diretor da Random House; editor de sua marca, Mark Macleod Livros, na editora Hachette Australia; além de apresentador de rádio e Presidente Nacional do Conselho do Livro Infantil da Austrália. Ensina Literatura Infantil e Escrita Criativa na Universidade Charles Sturt, em Sydney, Austrália. Entre seus livros mais recentes, estão A Treasure Chest of Rhymes (Bolinda Audio), coletânea de 40 poemas líricos para crianças musicados por Peter Sullivan; o livro de imagens Just One More (ABC Books); e, no Brasil, Onde Deus está? (Editora Fundamento, 2011)].
} 
The Invention of Hugo Cabret is a hybrid text: in its 534 pages there are only 26.159 words (Selznick 2007, p. 511), accompanied by 322 pages of black and white pencil illustrations, movie stills and archival photographs. Described on its title page as "A Novel in Words and Pictures", it is referred to by Australian artist Shaun Tan $(2011$, p. 6) as a "graphic novel', by Clement and Long (2012) as a "semi-graphic novel" and yet, controversially, the American Library Association awarded it the 2008 Caldecott Medal, which is the United States' highest award for a picture book. The illustrations do not merely render the narrative content of the words. The illustrated sequences that sometimes extend for 20 or 30 pages function like short silent movies, a feature highlighted by the Caldecott Medal judges' citation: "this tale casts a new light on the picture book form... Neither words nor pictures alone tell this story" (ALA, 2008). So visual is the emphasis in the novel that Anderson (2012) says in reference to the subsequent film adaptation: "it's hard to believe Scorsese hadn't conceived it in the first place".

Hugo lives in an abandoned worker's apartment and in the spaces behind the walls of Montparnasse railway station in Paris in 1931. From the catwalks high above the busy concourse and through gaps in the station's clock faces, he watches the old man who sits all day behind the toy booth counter below, and he waits for opportunities to gather up any spare parts that are lying around. Hugo is trying to repair an old automaton. He wants tools, cogs, anything to help him get this "mechanical man" going again. He believes that if he succeeds, it will give him a message from his dead father.

The automaton was created by one of the magicians who became pioneers of the film industry in the $19^{\text {th }}$ century: Georges Méliès. It turned up in a museum where Hugo's father worked, but no one remembered how it had got there or cared. The reader is told in an early flashback that Hugo's father, a clockmaker, has seen automata before, but he rescues this one and tells Hugo that it is special. No mere mechanical singing bird, it has a pen in its hand and can write. Hugo encourages his father to repair it. When his father is suddenly killed in a museum fire, Hugo blames himself for having urged his father to spend so much time on the repairs and he retrieves the automaton from the burnt rubble. It is all that he has left of his father and becomes the central reason for his continuing to live. The automaton, then, becomes his father, and the potential source of meaningful language. 
So the mechanical man who becomes Hugo's only companion before the narrative begins has been rescued twice from abjection: once by Hugo's father, and later by Hugo himself. Lacan's interpretation of the Symbolic stage entails separation from the mother and attachment to the father to facilitate the acquisition of language and therefore the construction of the self (JOHNS BLACKWELLL, 1999, p. 312). Hugo's separation from his mother is absolute; she is not even referred to. Selznick comments that his readers often ask about this, and in early drafts he had considered including her, but she created narrative problems: "Initially I looked for places to put her into the story...But every time I even hinted at her it demanded more information. The plot was like a machine - everything fits tightly as it is" (Reading Today, 2008, p. 13).

His solution was to leave Hugo's mother out and hope that readers would be intrigued rather than irritated by her absence.

The old man at the toy booth accuses Hugo of trying to steal from him. He makes Hugo turn out his pockets and confiscates the notebook in one of them. It includes drawings of the mechanical man, which, he says, prove that Hugo is a thief. It is not revealed at this point that the toy seller is the retired film-maker Georges Méliès. He was the original maker of the mechanical man, so although the drawings in the notebook were done by Hugo's father, the old man feels entitled to ownership of the notebook, since it reproduces his creation. Hugo is devastated and calls the old man a thief. He follows him home after work, and eventually enlists the help of Isabelle, the old man's goddaughter, who is also an orphan, as an accomplice to help him get his notebook back.

There are three generations of fathers here, and four generations of ownership through an emotional investment in the past. First, Méliès made the mechanical man and is in a sense its father, but Méliès lost all interest in his past when tastes in movies changed and audiences lost interest in him. Seeing the drawings of his invention in someone else's possession now suddenly rekindles his sense of entitlement. Second, as a child Hugo's father was taken to see Méliès's film Le Voyage dans la Lune and cherishes the memory of its sheer magic. One image in particular stays with Hugo's father: the spaceship that is launched from Earth pierces the eye of the Man in the Moon. When Hugo's father finds the abandoned mechanical man and learns that it was made by Méliès, it is an important link to his own father and his childhood memory of Méliès's film. So to Hugo's father, the mechanical man becomes 
Méliès - a father by proxy, since it was his own father who took him to the cinema. And third, since Hugo's father is dead, both the notebook drawings and their subject, the mechanical man, are not merely connected in Hugo's mind with his father - they are his father. Lacan refers to the object in which the subject projects himself as "the automaton in which, in an ambiguous relation, the world of his own making tends to find completion" (LACAN, 1989, p. 3). Anderson (2012) sees Hugo as "both lost boy and fatherly inventor, Pinocchio and Geppetto in one".

Hugo's quest for the mechanical man is therefore a quest for the subject that is the original artist's creation. The 'I'. Because the mechanical man is holding a pen, Hugo is sure that his purpose is to get it working again so that he can receive a written message from his father. When all the parts seem to be in place, it doesn't write, however - it draws. The sole image it draws is that of the Man in the Moon with the spaceship piercing his right eye. Then it writes: it signs the image 'Georges Méliès'. The relevance to an author who is both writer and illustrator is clear.

Clement and Long (2012) point out in another context the narrative's inclination to puns. Unsurprising, no doubt, in a narrative inspired by the early days of the film industry, the illustrations throughout The Invention of Hugo Cabret focus on eyes. There are eyes everywhere in close up - even the clock face looks like an eye - particularly in the long opening sequence of 21 wordless double-spread illustrations that finishes with the words, "From his perch behind the clock, Hugo could see everything" (SELZNICK 2007, p. 46). The implied mirroring of the boy Hugo and the girl who will be Isabelle is made quite explicit towards the end of the narrative, where they face one another in close up on 366-367 and 402403. On 238-239, as they watch the mechanical man begin to draw, on 376-377, as they gaze out through the clock face over the city at night, and when Méliès wraps his magician's cloak around them, apart from the haircuts, the children's heads in profile are almost identical and always feature wide open eyes (SELZNICK, 2007, p. 482-483).

The most significant pun in the text integrates both the word narrative and the picture narrative. It is the image of the spaceship landing on the Moon in Méliès' 1902 film. From the perspective of the early $21^{\text {st }}$ century, it is too easy to find fault with Méliès's remarkable envisioning, but as his astronauts embark on their flight to the Moon and later when they drop over the edge of a lunar cliff and are launched on the return trip to Earth, it is impossible to 
$\begin{array}{llllllll}R & \text { E } & \text { V } & \text { I } & \text { S } & \text { T } & \text { A } & \text { N. 24-2012.2-MARK MACLEOD }\end{array}$

avoid the impression that his spaceship is shaped like a bullet. So the image of a bullet penetrating the Man in the Moon - the image that Selznick himself saw as a child, and that stayed with him and inspired the book (SELZNICK, 2011, p. 12) - is an image of the wounded eye/I. The pen and ink rendition drawn by the mechanical man on pages 252-253 resolves an ambiguity in the original movie still that is included on pages 352-353: the spaceship does not just wound the eye/I; it completely obliterates it. Few details in this narrative are left to chance, and to emphasise the wounding, the character of Etienne - who does not appear in the film adaptation - wears a black patch over his right eye. He is no avatar of some cliché pirate or other malevolent fictional stereotype: he is a film student friend of Isabelle's, who sneaks the children into the cinema, gets fired for doing so, sees that Hugo is about to steal a book in Monsieur Labisse's shop and slips him a coin to pay for it, and introduces the children to René Tabard, the film historian who helps reconcile Hugo with Méliès and rehabilitate Méliès's reputation. If anything, then, Etienne's wounded eye represents a desire for healing and resolution of the artistic self.

The Invention of Hugo Cabret was contracted to Scholastic, the major publisher with direct access to the English-speaking schools market, and was therefore likely to be scrutinized as a potential text for study in the values curriculum. Perhaps as a consequence, the narrative frames Hugo's stealing carefully. The reader is told that it is only when Hugo's father dies and his alcoholic uncle Claude decides briefly to foster him that the boy learns to steal: "Uncle Claude taught Hugo how to steal, which Hugo hated more than anything, but some-times it was the only way to get something to eat" (SELZNICK, 2007, p. 126).

When Uncle Claude disappears and dies, Hugo must steal tools and spare parts so that he can keep the clocks going, continue living above the station and restore the mechanical man that is now symbolic of his father as the centre of his life. Hugo's intention to steal a book is also motivated by a longing for his dead father, who always read to him. The slow reconciliation between Hugo and Méliès advances considerably when Méliès agrees to teach him some card tricks. When the story starts, Méliès is in complete denial about his own past. He is just a toy seller, nothing more. So in passing on his tricks, Méliès revives his former career as a magician, and starts to become reconciled with himself as well.

Although stealing a book of tricks from the bookshop is therefore framed as understandable and possibly even forgivable, Etienne pulls a coin from under his eye patch, 
tells Hugo that this is the only trick he knows and gives him the coin to pay for the book. It is a gesture that recalls the coins on the eyes of the dead, placed there to weight the eyelids and to pay for the voyage across the River Styx - or, since it is one eye in this case, perhaps the half-dead. Hugo's theft of the heart-shaped key around Isabelle's neck is framed as another magic trick and justified once again by his need for a connection with his father. This key alone can start the mechanical man, and in any case it does not really belong to Isabelle: it was given to her by Méliès's wife, Mama Jeanne.

Although for most of the narrative Méliès is referred to by Isabelle's and Mama Jeanne's name for him, 'Papa Georges', he finally becomes Papa to Hugo, too: the creator of the mechanical man that represents the subsequent sons and fathers who have been connected with it - or 'him' - refers to his own apartment as Hugo's 'home' to save him being taken off to prison by the Station Inspector (SELZNICK, 2007, p. 479). Through the combined detective work of Isabelle, Hugo and the researcher René Tabard, Papa Georges embraces his own past as a 'cinema legend', as he is called on the invitation (SELZNICK, 2007, p. 493) to celebrate his life by the French Film Academy. At this gala occasion Tabard announces that 80 of his movies have been recovered and are being restored, and he screens a selection of them. The black and white illustrations in the narrative are now supplanted by a sequence of stills from Méliès's original movies.

After the screening, Papa Georges tells Hugo that he should remember this night as the first public performance ever given by Professor Alcofrisbas:

\footnotetext{
Hugo looked up and asked, 'Who is Professor Alcofrisbas?'

'You are, my boy! Professor Alcofrisbas was a character who appeared in many of my films, sometimes as an explorer, sometimes as an alchemist - a person who can turn anything to gold. But, mostly, he was a magician, and now he has appeared in real life, right here, in this very room.

In that moment the machinery of the world lined up. Somewhere a clock struck midnight, and Hugo's future seemed to fall perfectly into place (SELZNICK, 2007, p. 507).
}

Before a closing sequence of illustrations that zoom out from the Moon, the narrative draws to a conclusion with the short chapter "Winding Up". Clement and Long (2012) comment on the multiple meanings of this title. In it, the first person narrator from the single page introduction returns. Since the words scattered across the intervening five hundred pages 
have been in the third person, this narrator has effectively been forgotten. It is Professor Alcofrisbas, and he says that he has finally emerged from the child that was Hugo Cabret:

The automaton my father discovered did save me.

But now I have built a new automaton.

I spent countless hours designing it. I made every gear myself, carefully cut every brass disk, and fashioned every last bit of machinery with my own hands.

When you wind it up, it can do something I'm sure no other automaton in the world can do. It can tell you the incredible story of Georges Méliès, his wife, their goddaughter, and a beloved clockmaker whose son grew up to be a magician.

The complicated machinery inside my automaton can produce one hundred and fifty-eight different pictures, and it can write, letter by letter, and entire book, twenty-six thousand one hundred and fifty-nine words.

These words. (SELZNICK, 2007, p. 510-511).

And with that line, the word text comes to an end and the invention of Hugo Cabret is complete. This conclusion lays explicit claim to the brilliant complexity of the narrative and the central image of the entity that has been created - the man that can draw and write, the character Hugo, the story he tells - therefore proclaims subjectivity. It is inescapable, however, that the pejorative connotations of the labels 'automaton' and 'mechanical man' compromise the triumph of the moment, and construct it as a clever magician's trick. Selznick the writer, illustrator and film historian has introduced the work of Georges Méliès to a generation of readers both young and older, who will not have heard of him. He has restored Méliès's reputation as an innovator, by creating an innovative text himself. But the lingering doubt about the legitimacy of his own art is due to its sleight-of-hand, to its dependence on the art of his predecessors and to the Romantic assumption that true creativity is original. $\mathrm{He}$ has claimed his own subjectivity, but he has done so in homage to, but theft from, the past.

It is this dilemma that Scorsese's film adaptation addresses. And it does so by shifting the focus away from the subjectivity of the individual to the creative potential of relationships and community. Although as Anderson (2012) points out, The Invention of Hugo Cabret is a filmic novel, Clement and Long (2012) argue that conversely in Hugo, Scorsese creates a very book-conscious film. Even the 1902 Georges Méliès film that inspires Selznick is an adaptation of Jules Verne's 1865 novel De la Terre a la Lune (From the Earth to the Moon), so Méliès is not some original creator deity as implied by the reverence Hugo and his father 
have for his inventions. For Kristeva intertextuality is inevitable (SCHMITZ, 2005, p. 70), so the criterion of originality that clearly troubles Selznick is pointless. In a sense, artistic theft is not an issue because, as Geraghty (2009, p. 95) argues, an adaptation "draws attention to the fact of adaptation in the text itself".

Scorsese - and scriptwriter John Logan before him - shifts the emphasis of the narrative in two ways. First, he develops the roles of several minor characters into the B-story that in the Hollywood tradition of commercial film inevitably centres on romance. The café owner Madame Emilie, for example, now has a dachshund that bites her customer Monsieur Frick whenever he shows romantic interest in her, but he eventually succeeds in wooing her when he acquires an identical dachshund and introduces it to Madame Emilie's dog. And in another of the happy endings that the script says only happen in movies, the Station Inspector finally overcomes his shyness with women and, coached by Madame Emilie, succeeds in wooing the flower seller Lisette. The expanded role of the Station Inspector is the most dominant of these changes. This may partly be a result of casting the comic actor Sacha Baron Cohen, who would turn even a cameo into a leading role, but the Station Inspector's backstory helps to explain his relentless pursuit of a 12-year-old boy, whose crimes have little impact on anyone.

Whereas the main accusation against Hugo in the novel is that he is a thief, his greater crime in the film is that he is an orphan. Terrified that he is seeing his own possible fate, Hugo watches unseen as the Station Inspector captures a child, forces him to admit that he has no parents, and then shouts, 'Excellent! It's off to the orphanage with you!' and then the child is bundled into the paddy wagon by the police. When the Station Inspector does finally corner Hugo, he doesn't confront him with those who accuse him of theft, as he does in the novel. He bundles Hugo upstairs to his office and locks him in the tiny cell that is like a cage for a wild animal while he calls the police. The note of triumph in his words to Hugo is both palpable and revealing: "It's off to the orphanage with you. You'll learn a thing or two there. I certainly did. How to follow orders, how to keep to yourself, how to survive without a family. Because you don't need one. You don't need a family."

All the comic business to this point involving the Station Inspector's snarling but ineffectual dog Maximilian, and the complex mechanical brace on his left leg that gets caught on the departing train, drags him along the platform and later locks up and immobilizes him 
just as he works up the courage to approach Lisette - his whole expanded character suddenly begins to make sense.

From the perspective of $21^{\text {st }}$ century social welfare, it is difficult to understand how the tragedy of being without parents can be constructed as an accusation of crime, until marginalized members of society such as Indigenous Australians of the 'stolen generation' remind us that archaic laws were used in the past to charge children with the condition of being neglected, so that they could be made wards of the state (EVANS, 1999, p. 2; FORGOTTEN Australians Action Group). Orphans in $19^{\text {th }}$ century Europe can be read as an affront and embarrassment to the affluent society created by the industrial revolution. One way to appease any communal sense of guilt is to construct them not as victims, but as perpetrators - a perverse injustice satirized by Oscar Wilde's Lady Bracknell, when she rules that "To lose one parent... may be regarded as a misfortune; to lose both looks like carelessness" (WILDE, 1895, Act I).

Clearly, the Station Inspector's job involves sweeping any evidence of abjection in public spaces, such as orphans, out of sight. But his own past as an orphan, and his wound acquired in the war are the immediate explanations for his hounding of Hugo. More than any of the other minor characters whose difficulties with romance create the film's B-story, it is the Station Inspector who must learn that you can't survive without relationships, particularly those of a family.

Depending on the angle of shooting, the size of the automaton keeps changing in the film. When Hugo is jolted awake by his nightmares to see it from a low angle watching over him, it appears adult size, and yet when he races along the platform to tell Papa Georges that his precious creation has not been lost, the automaton is swathed in a white blanket and appears in a long shot to be about the size of a baby or large doll. This continuing ambiguity that positions Hugo as both child and parent confirms family connections for him and is endorsed by the props master's comment that the automaton's enigmatic smile is modelled on the Mona Lisa's (SELZNICK, 2011, p. 155). Although Selznick makes no attempt to draw a facial likeness between Hugo and the mechanical man in the novel, in the film its face appears alternately male and female, like the film Hugo himself, and its expression seems to respond to him (SELZNICK, 2011, p. 158-159). 
The scene in which Papa Georges secures Hugo's future and his release from the clutches of the Station Inspector is quite explicit about the film's shift in emphasis. When Hugo accidentally drops the mechanical man onto the railway line during the final chase and jumps down to retrieve it, the Station Inspector saves him - as he does in the novel - from being killed by the oncoming train. In the novel, Papa Georges tells Hugo he is "coming home' with him, which is a coded reassurance that somehow Hugo will become a member of his family, but in the film Papa Georges claims ownership of Hugo.

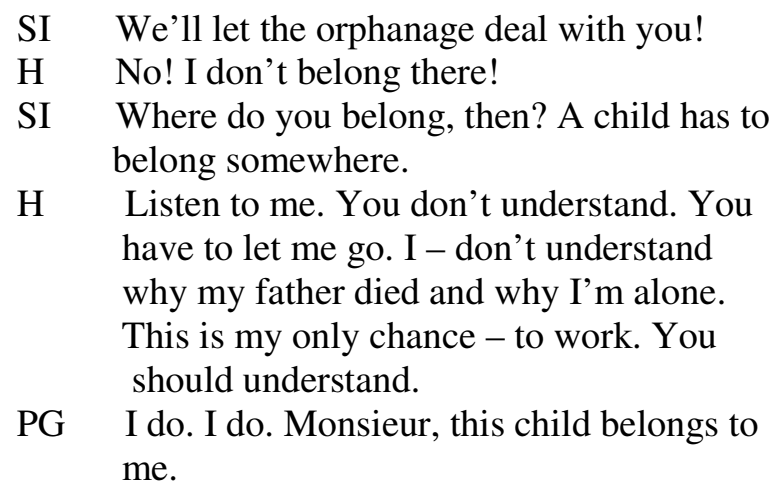

Then the celebration of Méliès's career at the Film Academy is directed by Scorsese as a coded exhortation to the film industry and to audiences in the $21^{\text {st }}$ century to remember the heritage of this art form that they enjoy and to keep it alive. Clearly although he has enjoyed exploiting the contemporary magic of 3-D technology in making the film, Scorsese constructs new technologies as participating in an ongoing tradition of narrative innovation. While the act of reading is on the whole traditionally done in isolation, film is consumed by viewers who are part of a group - notwithstanding the growing importance of delivery online and by DVD. There is no hint of creative guilt here. So at all levels, Hugo emphasizes the importance of connection: through human relationship, through the nurturing of creative communities, and through intertextuality.

Scorsese's film finally rejects the concept of the artist as either thief or orphan. Subjectivity can be claimed without the constructing of adversaries or guilt if the individual will accept it, because it participates in a continuous heritage that provides both an individual and a communal 'home'. As Papa Georges says when he assures the Station Inspector that the 


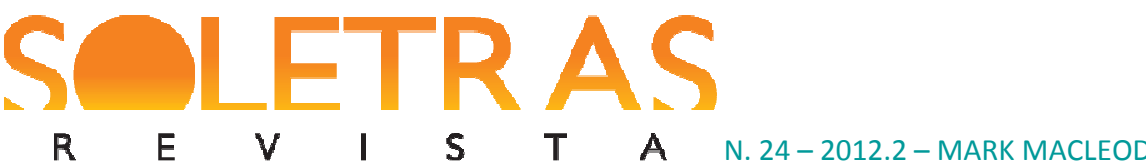

mechanical man he himself invented belongs to Hugo, 'You can't steal something that you already own, now can you?'

\section{Bibliography:}

ANDERSON, Jason (2012). 'The Re-Invention of Dreams: Martin Scorsese's Hugo', Cinema Scope Online. http://cinema-scope.com/cinema-scope-online/the-re-invention-of-dreams-martin-scorseseshugo/.

CLEMENT, J.; LONG, C. (2012). 'Hugo, Remediation, and the Cinema of Attractions, or, The Adaptation of Hugo Cabret'. Senses of Cinema 63, 22 July.

http://sensesofcinema.com/2012/feature-articles/hugo-remediation-and-the-cinema-ofattractions-or-the-adaptation-of-hugo-cabret/.

EVANS, C. (1999) Protecting the Innocent: Tasmania's Neglected Children, their Parents and State Care. http://eprints.utas.edu.au/14453/2/evans_part1.pdf.

FORGOTTEN Australians Action Group. http://www.forgottenaustralians.com/fapages/preamble.html.

GERAGHTY, C. (2009). Foregrounding the Media: Atonement (2007) as an Adaptation, Adaptation 2 (2): 91-109.

HUTCHEON, Lynda. A theory of adaptation. Oxford: Taylor \& Francos Group, 2006.

JOHNS BLACKWELL, M. (1999). Strindberg's Early Dramas and Lacan's "Law of the Father", Scandinavian Studies 71 (3): 311- 324.

LACAN, J. (1989). Ecrits: a selection (English trans. 1977). London: Routledge.

MÉLIÈS, G. (1902). Le voyage dans la lune. http://vimeo.com/39275260.

SANDERS, Julie. Adaptation and appropriation. New York: Routledge, 2006.

SCHMITZ, B. (J. Jansen trans.). (2005). Homelessness or Symbolic Castration? Subjectivity, Language Acquisition, and Sociality in Julia Kristeva and Jacques Lacan, Hypatia 20 (2): 6987.

SCORSESE, M. (2011). Hugo. GK Films, Paramount Pictures.

SELZNICK, B. (2011). The Hugo Movie Companion. New York: Scholastic Press. . (2007). The Invention of Hugo Cabret. New York: Scholastic Press.

UNKNOWN. Beyond Words. Reading Today (2008): 26 (1): 12-13. 


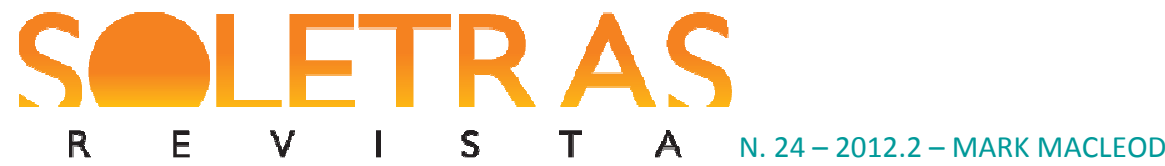

WILDE, O. (1895). The Importance of Being Earnest. In: The Importance of Being Earnest and Other Plays. (2008). Oxford: Oxford University Press.

\section{A invenção de Hugo Cabret, de Brian Selznick, Hugo, de Martin Scorsese, e o roubo da subjetividade}

Resumo: Sanders (2006) e Hutcheon (2006) estão entre os muitos teóricos da adaptação que desafiam o critério de "fidelidade", e, no entanto, uma referência frequente ao filme ganhador do Oscar, Hugo, é sobre sua fidelidade ao livro de Brian Selznick, premiado com a Caldecott Medal, The invention of Hugo Cabret. Este artigo discute que, em cada um dos casos, o meio determina uma diferença significativa na construção da subjetividade. subtextual e implícita do autor, em relação à dependência do seu trabalho ao de um outro artista. A mudança de ênfase do filme para a necessidade dos relacionamentos e para o tema da família, entretanto, encontra paralelo na ideia de Kristeva, de que a intertextualidade é inevitável. Conforme aponta Geraghty (2009), a adaptação é, por definição, dependente de outro texto. Consequentemente, o Hugo, de Scorsese, ignora a preocupação do livro com a originalidade e, em um tempo em que o cinema se reposiciona por meio da inovação tecnológica, celebra a continuidade e a herança do meio.

Palavras-chave: Hugo. Brian Selznick. Martin Scorsese. Subjectivity. Adaptation.

Recebido em: 15 de dezembro de 2012 .

Aprovado em: 02 de janeiro de 2013. 